\title{
Play, Children, \& Being Digital: Exploring Children's Autotelic Play in Digital Spaces
}

\author{
Fiona, M, Loudoun \\ PhD Candidate, University College Cork, Ireland \& Luleå University of Technology, Sweden \\ floudoun@ucc.ie
}

\begin{abstract}
Play for play's sake is viewed a child's primary occupation from which meaning is derived that transcends it's inherent health, educational or other such value. Examined from this perspective is to acknowledge the intrinsic contribution the doing of play contributes the child's being. The proliferation of technology in an ever-connected world offers increasingly diverse digital spaces for children to play. Such digital spaces present new opportunities for children to co-create new expressions of play; whether alone, with friends, indoors and outdoors, in real and in make-believe worlds. Despite literature in relation to play in digital spaces coming from a plethora of academic fields, this occupational perspective of play as a child-centred, autotelic pursuit remains largely ignored. This research will explore digital play choices, experiences, and outcomes from children's unique perspective. Furthermore, this research aims to reflect the rights and agency of children as meaning-makers and active contributors in inquiry [3], using creative and adaptive approaches through the research process.

It is envisioned that this research will contribute to the understanding of the autotelic nature of play in digital spaces. Such understanding will assist children and adults to leverage technology to ensure that meaningful playful experiences proliferate in the future.
\end{abstract}

\section{CCS CONCEPTS}

- Human-centered computing; • Human computer Interaction (HCI); • HCI design and evaluation methods; • User studies;

\section{KEYWORDS}

Play, digital spaces, children, participatory research

\section{ACM Reference Format:}

Fiona, M, Loudoun. 2021. Play, Children, \& Being Digital: Exploring Children's Autotelic Play in Digital Spaces. In Extended Abstracts of the 2021 Annual Symposium on Computer-Human Interaction in Play (CHI PLAY '21), October 18-21, 2021, Virtual Event, Austria. ACM, New York, NY, USA, 2 pages. https://doi.org/10.1145/3450337.3483517

Permission to make digital or hard copies of part or all of this work for personal or classroom use is granted without fee provided that copies are not made or distributed for profit or commercial advantage and that copies bear this notice and the full citation on the first page. Copyrights for third-party components of this work must be honored

For all other uses, contact the owner/author(s).

CHI PLAY '21, October 18-21, 2021, Virtual Event, Austria

(c) 2021 Copyright held by the owner/author(s).

ACM ISBN 978-1-4503-8356-1/21/10.

https://doi.org/10.1145/3450337.3483517

\section{INTRODUCTION}

The $21^{\text {st }}$ century has seen one of the most significant shifts in terms of digitalisation accelerated by rapid shifts in the accessibility of technology and digital devices. For children, certainly in most western societies, this means that they are confronted by an increasingly diverse range of leisure and play opportunities. Despite literature in relation to play in digital spaces coming from a plethora of academic fields, such as Computer Science, Sociology, Psychology, and Education, play from an occupational perspective has been largely ignored to date. This research will therefore explore the choices, experiences, and outcomes of children's participation in play in digital spaces from their own unique perspective.

\section{PLAY IN DIGITAL SPACES: DOING \& BEING}

Occupation is described as "what humans do when they act as agents of their own intentions” [19, pg. 91] with Occupational Science being the study of human occupation. Within the context of children and young people, play is acknowledged as a child's primary occupation. Much of the focus of recent research has been to identify the outcomes of play from an educational or developmental perspective; such as stimulating language, the social participation whilst playing, developing literacy or numeracy and the learning of playing on digital devices to support independent use [see for example; $8,18]$. Distinguishing play as an occupation focusses attention on its autotelic character rather than educational, developmental, or therapeutic value. From this perspective children's participation is characterised as the being or doing of play for play's sake. Globally, the United Nations Convention on the Rights of the Child [17] has firmly re-positioned children's agency in their participation in society, acknowledging them not only as the holder of rights but also able to share and make meaning from their unique perspective of the world [3].

\section{RESEARCH CONTEXT AND APPROACH}

Although there has been an increase in interest in research examining the nature of autotelic play in diverse backgrounds and environments such as playgrounds [10], urban spaces [9] and in rural settings such as forests [16], explorations of play for play's sake in digital spaces has remained largely ignored to date. By acknowledging the contemporary occupation of play in digital spaces comprising of a complex interplay of people, environments, objects (both real and virtual) and cultural dimensions; the transactional approach enables the position of agency and occupational identity to be established $[12,13]$. Plowman [14] provides a broad definition of digital play being "activities children choose to do using digital devices and toys” (pg.56). To consider the interactivity afforded by digital play, four levels are indicated by Flynn et al [5]; receptive, manipulative, embodied, and contingent interactivity. However, the 
complexity of interactivity is acknowledged within the as the opportunities provided will offer distinct play affordances dependent on the social and physical environment, the players' skill, their level of motivation and volition in that given moment [11]. Bird \& Edwards [1] interprets Hutt's taxonomy of play to explore the breadth of affordances of digital play in relation to the epistemic and ludic characteristics; the former being what knowledge is obtained through play where children explore, problem solve and develop new skills. From this perspective, play that draws on children's previous experiences is referred to as ludic. As children learn to operate and engage with devices and digital objects (epistemic play), their play becomes more ludic; demonstrating the use of their imagination and creativity [6, 7]. The constant challenge provided by playing in digital spaces can be explored by considering 'flow' whereby individuals experience a state of complete engagement with temporary loss of consciousness of time and space [4]. The conditions for 'flow' explore the fit between the individuals' perceived skills and competence and the challenge provided by the activity as well as the immediate feedback provided [15]. This research will explore the choices made by children and the affordances provided by participating in meaningful play in digital spaces for children as well as its impact on well-being and overall participation. The key viewpoint in this research will be from the child's perspective. As such, the composite studies in this $\mathrm{PhD}$ will draw on Clark's mosaic approach [2] and employ creative engagement and data gathering techniques and tools, including photo-elicitation interviews, observation and focus groups that are guided by participating children.

\section{CURRENT PROGRESS AND EXPECTED CONTRIBUTIONS}

This $\mathrm{PhD}$ commenced in January of 2021 and will be completed by publication over the course of the next three years. It will comprise of a series of four interconnected studies each building upon the results of the previous and the researcher's evolving understanding of play from an occupational perspective. It is anticipated that this research will contribute to improve the knowledge and understanding of play in digital spaces as an occupation; highlighting the intrinsic, autotelic nature of play from the unique perspectives of children.

Study 1 will consist of a scoping review to explore the current extent of research from a child's perspective. Studies 2, $3 \& 4$ will follow the trajectory of childhood to explore play in digital spaces from the perspective of children and young people.

At present (August 2021), the Ethics application has been submitted and approved by SREC at University College Cork, Ireland and the Swedish Ethical Review Board. The scoping review has commenced and is due to be completed by September 2021. This will then enable recruitment and data collection to commence.

\section{ACKNOWLEDGMENTS}

This project has received funding from the European Union's Horizon 2020 research and innovation programme under grant agreement No: 861257 (P4Play project: www.p4play.eu). I would like to thank my supervisors, Dr Bryan Boyle at University College Cork and Professor Maria Larsson-Lund at Luleå University of Technology for their expert support and guidance.

\section{REFERENCES}

[1] Bird, J., \& Edwards, S. (2015). Children Learning to Use Technologies through Play: A Digital Play Framework. British fournal of Educational Technology, 46(6), 1149-1160. http://dx.doi.org/10.1111/bjet.12191

[2] Clark, A. (2001). How to listen to very young children: The mosaic approach. Child Care in Practice, 7(4). https://doi.org/10.1080/13575270108415344

[3] Clark, A. (2017). Listening to Young Children: A Guide to Understanding and Using the Mosaic Approach (3rd ed.). Jessica Kingsley Publishers.

[4] Czikszentmihalyi, M. (2002). Flow: The classic work on how to achieve happiness (2nd ed.). Rider Books.

[5] Flynn, R. M., Richert, R. A., \& Wartella, E. (2019). Play in a Digital World: How Interactive Digital Games Shape the Lives of Children. American fournal of Play, 12(1), 54-73.

[6] Hatzigianni, M., Gregoriadis, A., Karagiorgou, I., \& Chatzigeorgiadou, S. (2018). Using tablets in free play: The implementation of the digital play framework in Greece. British fournal of Educational Technology, 49(5), 928-942. https://doi.org/ 10.1111/bjet.12620

[7] Lundtofte, T. (2020). Young Children's Tablet Computer Play. American fournal of Play, 12(2), 216-232.

[8] Marsh, J. (2010). Young children's play in online virtual worlds. Fournal of Early Childhood Research, 8(1), 23-39. https://doi.org/10.1177/1476718X09345406

[9] Min, B., \& Lee, J. (2006). Children's neighborhood place as a psychological and behavioral domain. Journal of Environmental Psychology, 26(1), 51-71. https: //doi.org/10.1016/j.jenvp.2006.04.003

[10] Moore, A., \& Lynch, H. (2015). Accessibility and usability of playground environments for children under 12: A scoping review. Scandinavian fournal of Occupational Therapy, 22(5), 331-344. https://doi.org/10.3109/11038128.2015.1049549

[11] Mustola, M., Koivula, M., Turja, L., \& Laakso, M.-L. (2018). Reconsidering passivity and activity in children's digital play. New Media \& Society, 20(1), 237-254. https: //doi.org/10.1177/1461444816661550

[12] Nyman, A., Josephsson, S., \& Isaksson, G. (2014). A narrative of agency enacted within the everyday occupations of an older Swedish woman. fournal of Occupational Science, 21(4), 459-472. https://doi.org/10.1080/14427591.2013.803433

[13] Phelan, S. K., \& Kinsella, E. A. (2014). Occupation and identity: Perspectives of children with disabilities and their parents. In fournal of Occupational Science (Vol. 21, Issue 3, pp. 334-356). Routledge. https://doi.org/10.1080/14427591.2012.755907

[14] Plowman, L. (2020). DIGITAL PLAY. University of Edinburgh. Available at: https://www.de.ed.ac.uk/sites/default/files/2020-07/Digital\%20Play\%20\%20Plowman\%202020.pdf

[15] Rebeiro, K. L., \& Polgar, J. M. (1999). Enabling occupational performance: Optimal experiences in therapy. Canadian fournal of Occupational Therapy, 66(1), 14-22.

[16] Ridgers, N. D., Knowles, Z. R., \& Sayers, J. (2012). Encouraging play in the natural environment: A child-focused case study of Forest School. Children's Geographies, 10(1), 49-65. https://doi.org/10.1080/14733285.2011.638176

[17] UNCRC. (1989). The United Nations Convention on the Rights of the Child.

[18] Verenikina, I., Kervin, L., Rivera, M. C., \& Lidbetter, A. (2016). Digital play: Exploring young children's perspectives on applications designed for preschoolers. Global Studies of Childhood, 6(4). https://doi.org/10.1177/2043610616676036

[19] Yerxa, E. (2000). Occupational science: A renaissance of service to humankind through knowledge. Occupational Therapy International, 7(2), 87-98 